\title{
GRAVIMETRIC AND SPECTROSCOPIC STUDIES OF REVERSIBLE HYDROGEN SORPTION ON NANOPOROUS CLINOPTILOLITE
}

\author{
P. Lesnicenoks, L. Grinberga, J. Kleperis \\ Institute of Solid State Physics, \\ University of Latvia, \\ 8 Kengaraga Street, Riga, LV-1063, Latvia \\ e-mail: kleperis@latnet.lv
}

\begin{abstract}
Large surface aluminosilicate compounds such as zeolites are not the best option for hydrogen storage due to their low hydrogen sorption capacity above cryogenic temperatures. However, the known crystal structure and easy ion exchange allows considering zeolites as easily tuneable media that with a little effort can be changed to suitable porous media for hydrogen sorption. Metal ( $\mathrm{Li}, \mathrm{Mg}$ ) and ammonia ion exchange is performed in natural clinoptilolite samples with the aim to increase the amount of adsorbed hydrogen. The Fourier transform infrared spectroscopy of the prepared samples is used to study sorption of hydrogen molecules in the vicinity of light metal ions. An original thermogravimetric method is applied to characterise the amount of sorbed hydrogen. Our experiments show that the highest hydrogen uptake $(\sim 6.2 \mathrm{wt} \%)$ is for a clinoptilolite sample treated in acid. The cation exchange did not provide the expected hydrogen sorption capability; however, the amount of sorbed hydrogen exceeded that for the initial material.
\end{abstract}

Keywords: zeolites, hydrogen sorption, gravimetry, FTIR analysis

\section{INTRODUCTION}

Increasing demand for energy is fuelling the research on more efficient and less polluting ways to manufacture, store and use energy. Hydrogen is considered as ecological-friendly energy carrier with high energy density. To fully integrate it in the energy circulation, of importance is to find an efficient enough and safe way of storing hydrogen. So far, high-pressure storage tanks, liquefied hydrogen storage tanks, metal hydrides, some metal-organic frameworks and mesoporous materials are under investigation [1-4]. The aim established by European Union is to develop by 2015 the material that would provide at least $10 \mathrm{wt} \%$ of stored hydrogen [5].

The interest in zeolites as hydrogen storage materials results from their high internal surface area of pores that are suitable for the physisorption of hydrogen. Another advantage of zeolites is their thermal and chemical stability. Zeolites are crystalline alumosilicate minerals consisting of frameworks of $\left[\mathrm{SiO}_{4}\right]^{4}-$ and $\left[\mathrm{AlO}_{4}\right]^{5}$-tetrahedra that form different open structures. Each $\mathrm{AlO}_{4}$ tetrahedron 
carries a net negative charge that is balanced by additional non-framework cations like sodium, potassium or calcium [6].

The presence of these exchangeable cations grants tuning of characteristics; for instance, transition metals could be used to improve the binding of hydrogen within the zeolite. On the other hand, size of the cation could be used to tune the pore size and the free pore space. Usage of different exchangeable cations provides different thermodynamic heat of sorption. This makes it possible to provide improved sorption of hydrogen at higher temperatures.

Al Sacco, director of the NASA-supported Centre for Advanced Microgravity Materials Processing at North-Eastern University, Boston (USA) in the frame of NASA research project is investigating the suitability of zeolite as material for storage of at least $7 \mathrm{wt} \%$ of hydrogen. The basic idea is here that some negatively-charged ions in zeolite act like caps, blocking the crystalline pores of zeolites. By heating a tank with zeolite it is possible to make the ions move away from the pores and fill with hydrogen, but dropping the temperature back to normal the ions slide back in place, sealing off the exits [7].

Our research is focused on a natural zeolite - clinoptilolite. The performed ion exchange and sample treatment experiments are discussed. The Fourier transform infrared (FTIR) spectroscopy and thermogravimetric method are used to characterize the samples and hydrogen sorption properties.

\section{SAMPLE PREPARATION}

Samples for investigating the natural zeolite clinoptilolite were taken from a deposit in the Ukraine. No special sample preparation was done for X-ray diffraction (XRD), the BET surface area and Energy Dispersive X-ray analysis (EDAX). Before experiments, some zeolite samples were washed in deionised water 4-5 times. Other samples were treated with oxalic acid $\left(\mathrm{C}_{2} \mathrm{H}_{2} \mathrm{O}_{4}\right)$ to purify the raw zeolite from iron oxides as suggested by Tschernich [8].

The $1 \mathrm{ml} / 1$ salt solutions were prepared to exchange cations in zeolite. For the magnesium, lithium and ammonia ion exchange the washed zeolite samples were placed in $1 \mathrm{M}$ salt solutions of $\mathrm{MgCl}_{2}, \mathrm{CH}_{3} \mathrm{COOLi}$ and $\mathrm{ClH}_{4} \mathrm{~N}$, respectively. The solutes were mixed by magnetic stirring in deionised water for $48 \mathrm{~h}$ at $40^{\circ} \mathrm{C}$. After the ion exchange procedures the samples were washed with deionised water at least 3 times and dried in air at $100^{\circ} \mathrm{C}$ for $12 \mathrm{~h}$.

\section{SAMPLE CHARACTERIZATION}

The initial samples were characterized by the XRD method using an $X^{\prime}$ Pert Pro MPD diffractometer with $\mathrm{CuK} \alpha$ radiation $(\lambda=1.5418 \AA)$. The sample composition was then compared with the database. For determination of the pore size and the surface volume of zeolites the BET method (Nova 1200 E-Series, Quantachrome Instruments) was used. The elemental composition of zeolite samples was determined by EDAX analysis (EDAX/Ametek - Eagle III microprobe). The FTIR analysis was performed for the samples after washing in water and acid as well as after the ion exchange experiments. 
The thermogravimetric hydrogen sorption method has been elaborated in our laboratory [9] based on a differential thermal gravimetric device Shimatzu $D T A / T G-60$. This method was chosen because of its easiness and high repeatability

\section{RESULTS AND DISCUSSION}

The area of our samples' pore surface determined using the BET method was $23.03 \mathrm{~m}^{2} / \mathrm{g}$. The relevant calculation gives the value of $\sim 1.8 \mathrm{wt} \%$ for hydrogen sorption by the initial sample of zeolite, assuming that a monolayer of adsorbed molecules is formed.

Table 1

Table 2

Elemental composition of samples washed in water, atomic \%

\begin{tabular}{c|c|c|c|c} 
& $\begin{array}{c}\text { Washed } \\
\text { with } \\
\text { water }\end{array}$ & $\mathrm{Mg}$ & $\mathrm{NH}_{3}$ & $\mathrm{Li}$ \\
\hline $\mathrm{Al}$ & 13.95 & 13.03 & 12.2 & 13.05 \\
\hline $\mathrm{Si}$ & 61.53 & 66.59 & 71.49 & 64.37 \\
\hline $\mathrm{K}$ & 15.59 & 10.54 & 10.87 & 10.68 \\
\hline $\mathrm{Ca}$ & 4.19 & 4.78 & 2.47 & 4.25 \\
\hline $\mathrm{Ti}$ & 0.45 & 0.74 & 0.43 & 0.44 \\
\hline $\mathrm{Fe}$ & 4.2 & 4.23 & 2.48 & 7.1 \\
\hline $\mathrm{Sr}$ & 0.09 & 0.09 & 0.06 & 0.11 \\
\hline $\mathrm{Si} / \mathrm{Al}$ & 4.41 & 5.11 & 5.86 & 4.93
\end{tabular}

Elemental composition of samples washed in water and acid, atomic \%

\begin{tabular}{c|c|c|c|c} 
& $\begin{array}{c}\text { Washed } \\
\text { with } \\
\text { acid }\end{array}$ & $\mathrm{Mg}$ & $\mathrm{NH}_{3}$ & $\mathrm{Li}$ \\
\hline $\mathrm{Al}$ & 9.01 & 9.28 & 9.33 & 9.5 \\
\hline $\mathrm{Si}$ & 70.65 & 73.17 & 79.49 & 72.42 \\
\hline $\mathrm{K}$ & 14.64 & 10.95 & 7.61 & 7.91 \\
\hline $\mathrm{Ca}$ & 1.8 & 2.26 & 0.51 & 6.55 \\
\hline $\mathrm{Ti}$ & 0.47 & 0.45 & 0.48 & 0.59 \\
\hline $\mathrm{Fe}$ & 3.38 & 3.81 & 2.53 & 2.92 \\
\hline $\mathrm{Sr}$ & 0.05 & 0.08 & 0.05 & 0.11 \\
\hline $\mathrm{Si} / \mathrm{Al}$ & 7.84 & 7.88 & 8.52 & 7.62
\end{tabular}

Different procedures for treatment of zeolite samples are applied to increase the sorbed amount of hydrogen so that they can be used as storage materials. The XRD analysis compared with database [10] indicated that the natural zeolite samples consist mostly of a mineral - the clinoptilolite with a small addition of quartz.

The EDAX elemental analysis (Tables 1 and 2) evidences the presence of high amount of $\mathrm{Fe}$. Its concentration changes from 2.5 to 8 at $\%$ after different ion exchange treatments. Important conclusion from the EDAX results is that the treatment of zeolite in oxalic acid markedly increases the $\mathrm{Si} / \mathrm{Al}$ ratio up to 7 (for typical clinoptilolite structure $\mathrm{Si} / \mathrm{Al}$ is < 4) [11].

Typically, the FTIR spectroscopy is used to specify the structure of zeolites and to monitor reactions in zeolite pores, while the vibration frequencies are mostly in the range $200-1500 \mathrm{~cm}^{-1}$ [12]. In the $\mathrm{O}-\mathrm{H}$ stretching region, the infrared spectra of zeolites contain information on the hydroxyl groups attached to zeolite structures. 


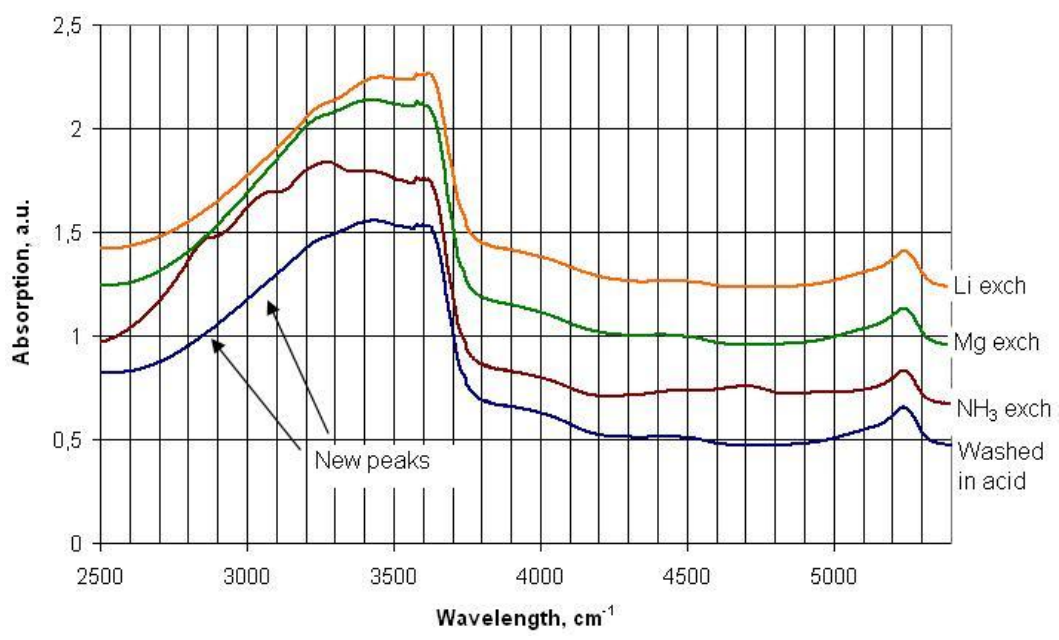

Fig. 1. FTIR spectra of washed in acid and ion-exchanged clinoptilolite - near-IR region where three new peaks arise in the ammonia-exchanged clinoptilolite sample: $\sim 4830 \mathrm{~cm}^{-1}, \sim 3080 \mathrm{~cm}^{-1}$ and $\sim 2850 \mathrm{~cm}^{-1}$.

In Fig. 1, from five types of hydroxyl groups found in zeolites: lattice termination silanol groups $\left(\sim 3745 \mathrm{~cm}^{-1}\right)$; hydroxyl groups occurring at defect sites $\left(\sim 3720 \mathrm{~cm}^{-1}\right)$; OH-groups attached to cations which compensate the negative charge of the framework $\left(\sim 3695 \mathrm{~cm}^{-1}\right)$; OH-groups attached to the extra framework alumina (EFAL) species $\left(\sim 3655 \mathrm{~cm}^{-1}\right)$; and bridging OH-groups with Bronsted acidity ( 3630 and $\left.3560 \mathrm{~cm}^{-1}\right)$ - in FTIR spectra only two last can be noticed. Three new peaks are present in the ammonia-exchanged clinoptilolite sample in the far IR spectra $\left(\sim 4830 \mathrm{~cm}^{-1}, \sim 3080 \mathrm{~cm}^{-1}\right.$ and $\left.\sim 2850 \mathrm{~cm}^{-1}\right)$ and one (seen in Fig. 2) in the near IR spectrum $\left(\sim 1450 \mathrm{~cm}^{-1}\right)$ which cannot be explained by vibrations of nitrogen-related groups in the zeolite framework [13].

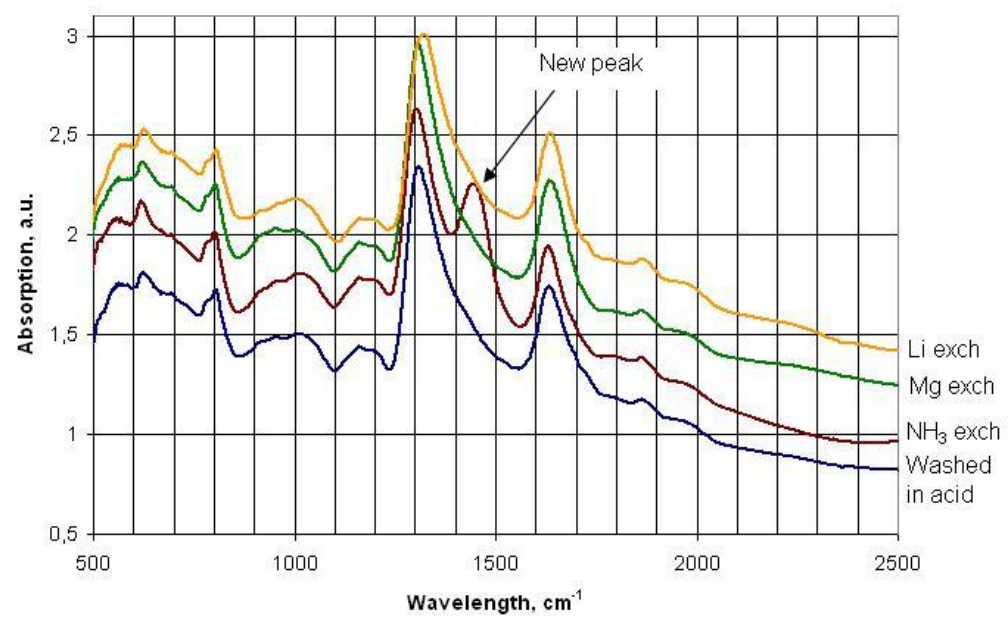

Fig. 2. FTIR spectra of washed in acid and ion-exchanged clinoptilolite, with an extra peak $\sim 1450 \mathrm{~cm}^{-1}$ in the far IR region.

Different metal ions are of great importance in promoting the hydrogen sorption in zeolites; therefore, we used $\mathrm{Li}$ and $\mathrm{Mg}$ ion exchange in clinoptilolite. 
Nevertheless, the measurements by thermogravimetric method gave the highest values of adsorbed hydrogen (up to $6.2 \mathrm{wt} \%$ ) for the zeolite washed in oxalic acid (Fig. 3); a slightly lower values of sorbed hydrogen are for the $\mathrm{Mg}$ exchanged sample (5.6 wt\%), ammonia (3.5 wt\%) and Li-exchanged zeolite treated in acid $(1.8 \mathrm{wt} \%)$. The worse results are for samples washed only with water: $\mathrm{Mg}-$ $3.8 \mathrm{wt} \%$; ammonia - $2.1 \mathrm{wt} \%$; and $\mathrm{Li}-1.7 \mathrm{wt} \%$.

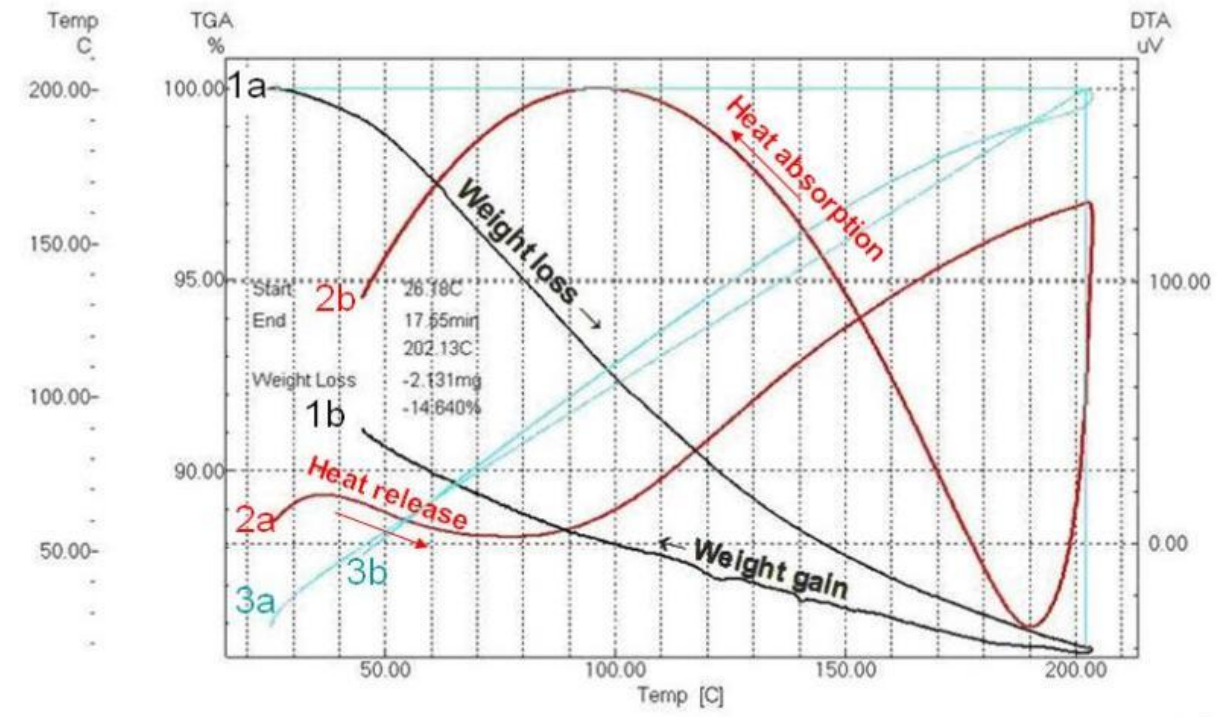

Fig. 3. Thermogravimetric hydrogen sorption results for the clinoptilolite sample washed in acidic media. $1 \mathrm{a}$ and $1 \mathrm{~b}$ - weight loss and gain;

$2 \mathrm{a}$ and $2 \mathrm{~b}$ - temperature difference between sample and reference;

$3 \mathrm{a}$ and $3 \mathrm{~b}-$ temperatures on sample and reference thermocouples.

To explain the results obtained with the thermogravimetric method, a hydrogen encapsulation mechanism in zeolite was suggested in 1990 by Brunner [14] and later reported by Weitkamp [15] and Sacco [7]. To specify a possible mechanism for such kind of encapsulation it might be mentioned that the heat treatment in the presence of inert gas flow at atmosphere pressure leaves the pores in zeolite at a slightly stressed state; small hydrogen molecules can easily penetrate the stressed pores while exchanging gas at a high temperature from inert to hydrogen. Less-porous fractions of natural clinoptilolite sample (quartz) may be involved in the hydrogen spillover process supplying the atomic hydrogen to zeolite particles [16].

\section{CONCLUSIONS}

The metal $(\mathrm{Li}, \mathrm{Mg})$ and ammonia ion exchange has successfully been performed in natural clinoptilolite samples with the aim to increase the amount of sorbed hydrogen. The thermogravimetric method for studying hydrogen sorption in solid materials has been elaborated and successfully tested. The hydrogen sorption- 
desorption cycle in palladium powder is shown to be a good verification test for this purpose, and it is found that the obtained sorbed-desorbed hydrogen values are reliable.

The washed in water and in acid zeolite samples as well as the ionexchanged samples have been tested in the thermogravimetric sorption-desorption cycle and the highest amount of sorbed hydrogen (up to $6.2 \mathrm{wt} \%$ ) is found for the washed in acid clinoptilolite. The ion exchange decreases the hydrogen sorption capability of zeolite in the row (from best to worse): $\mathrm{Mg}, \mathrm{NH}_{3}, \mathrm{Li}$.

Further experiments must be done along with reversibility tests; results of our experiments show that these materials could be reversible and potentially applicable for the storage tanks in vehicles.

\section{ACKNOWLEDGEMENTS}

The authors acknowledge the National Research Programme LATENERGI for financial support.

\section{REFERENCES}

1. Ahluwalia, RK, Hua, TQ, Peng, JK, Lasher, S, McKenney, K., Sinha, J. \& Gardiner, M. (2010). Int. J. Hydrogen Energy, 35, 4171.

2. Sakintuna, B., Lamaridarkrim, F., \& Hirscher, M. (2007). Int. J. Hydrogen Energy, 32, 1121.

3. Yu Y, Zhao N, Shi C, He C, Liu E, Li J. (2012). Int. J. of Hydrogen Energy, 37, 5762.

4. Zheng J, Liu X, Xu P, Liu P, Zhao Y, Yang J. (2012). Int. J. Hydrogen Energy, 37, 1048.

5. Tzimas E, Filiou C, Peteves SD, Veyret JB (2003). Hydrogen Storage: State-of-the-Art and Future Perspective. The Netherlands, Institute for Energy - JRC IE.

6. Bogdanov, B., Georgiev, D., Angelova, K., \& Yanevak (June 4-5, 2009). Proceedings Int. Sc.conf. on: Economics and Society development on the Base of Knowledge, Stara Zagora, Bulgaria.

7. Rocks in your Gas Tank. NASA Everyday News: http://www.nasa.gov

8. Tschernich, R.W. (1992). Zeolites of the World. Geoscience Press.

9. Lesnicenoks, P., Sivars, A., Grinberga, L., \& Kleperis, J. (2012). IOP Conf. Ser.: Mater. Sci. Eng., 38, 012060.

10. The mineral and locality database: www. mindat.org

11. Jentys, A., \& Lercher, J.A. (2001). Studies in Surface Science and Catalysis, Vol. 137, Elsevier Science, B.V., Amsterdam.

12. Karge, H.G. (1998). Micro. Meso Mater., 22, 547.

13. Song, W., Light, G., Grassian, VH, \& Larsen, SC (2005). Environ. Sci. Tech., 39, 1214.

14. Brunner, GO (1990). Zeolites, 10, 612.

15. Weitkamp, J. (2009). Encyclopedia of Electrochemical Power Sources: Fuels Hydrogen Storage Zeolites.

16. Ginberga, L., \& Kleperis. J. (2011). Composite Nanomaterials for Hydrogen Technologies. In: Advances in Composite Materials for Medicine and Nanotechnology, InTech, 04/2011. 


\title{
GRAVIMETRIJAS UN SPEKTROSKOPIJAS PĒTĪJUMI \\ ATGRIEZENISKAI ŪDEN̦RAŽA ADSORBCIJAI \\ UZ NANOPORAINA KLINOPTILOLĪTA
}

\author{
P. Lesničenoks, L. Grīnberga, J. Kleperis
}

\section{Kopsavilkums}

Lielas virsmas alumosilikāta savienojumi, piemēram, ceolīti, nav labākais risinājums ūdeņraža uzglabāšanai, ņemot vērā to niecīgo sorbētā ūdeņraža daudzumu temperatūrā, kas augstāka par kriogēno. Tomēr zināmā kristāla struktūra un vieglā jonu apmaiņas iespēja paver iespēju izmantot ceolītus kā viegli pielāgojamu materiālu, kuru ar nelielām modifikācijām var pārveidot par piemērotu vidi ūdeņraža sorbcijai. Darbā metālu $(\mathrm{Li}, \mathrm{Mg})$ un amonjaka jonu apmaiņa tiek veikta dabīgā klinoptilolīta paraugos ar mērḳi palielināt sorbētā ūdeņraža daudzumu materiālā. Furjē infrasarkanā spektroskopija tiek izmantota, lai pêtītu ūdeņraža molekulas sorbciju vieglo metālu jonu tuvumā. Oriǵināla termogravimetrijas metode tiek pielietota, lai raksturotu uzkrātā ūdeņraža daudzumu paraugos. Eksperimentālie rezultāti liecina, ka vislielākais uzkrātā ūdeņraža daudzums ( 6,2 masas\%) ir ar skābi apstrādātam klinoptilolīta paraugam. Katjonu apmaiņa nesniedza gaidīto pozitīvo rezultātu, tomēr sagatavotie paraugi uzrādīja lielāku sorbētā ūdeṇraža daudzumu, nekā sākotnējie neapstrādātie paraugi.

26.05.2014. 